\title{
MITIGATING THE $4^{\text {th }}$ WAVE OF THE COVID-19 PANDEMIC IN ONTARIO
}

September 1, 2021

Lauren E. Cipriano ${ }^{1,2,3}$

Wael M. R. Haddara ${ }^{4,5}$

Beate Sander ${ }^{3,6,7,8}$

1. Ivey Business School, Western University

2. Department of Epidemiology and Biostatistics, Schulich School of Medicine and Dentistry, Western University

3. Toronto Health Economics and Technology Assessment (THETA) collaborative, University Health Network

4. Department of Medicine, Schulich School of Medicine \& Dentistry, Western University

5. Division of Critical Care, London Health Sciences Centre

6. Institute of Health Policy, Management and Evaluation, University of Toronto

7. Public Health Ontario

8. ICES

Funding: This work was supported in part by the Gordon and Betty Moore Foundation through Grant GBMF9634 to Johns Hopkins University to support the work of the Society for Medical Decision Making COVID-19 Decision Modeling Initiative (co-PIs: Cipriano and Enns), a Western University Catalyst Research Grant (PI: Cipriano [Grant \#R5171A06]), a Canada Research Chair in Healthcare Analytics, Management, and Policy held by Lauren Cipriano (CRC-950-233070), and a Canada Research Chair in Economics of Infectious Diseases held by Beate Sander (CRC-950-232429).

\section{Corresponding author:}

Lauren Cipriano

Ivey Business School at Western University

1255 Western Road

London ON N6G 0N1

P: 519-661-4181

E: Icipriano@ivey.uwo.ca

Keywords: hospital capacity planning; infectious disease modeling; novel coronavirus; intensive care capacity; covid-19; covid-19 non-pharmaceutical interventions 


\section{ABSTRACT}

Background: The goal of this study was to project the number of COVID-19 cases and demand for acute hospital resources for Fall of 2021 in a representative mid-sized community in southwestern Ontario. We sought to evaluate whether current levels of vaccine coverage and contact reduction could mitigate a potential $4^{\text {th }}$ wave fueled by the Delta variant, or whether the reinstitution of more intense public health measures will be required.

Methods: We developed an age-stratified dynamic transmission model of COVID-19 in a mid-sized city (population 500,000) currently experiencing a relatively low, but increasing, infection rate in Step 3 of Ontario's Wave 3 recovery. We parameterized the model using the medical literature, grey literature, and government reports. We estimated the current level of contact reduction by model calibration to cases and hospitalizations. We projected the number of infections, number of hospitalizations, and the time to re-instate high intensity public health measures over the fall of 2021 under different levels of vaccine coverage and contact reduction.

Results: Maintaining contact reductions at the current level, estimated to be a $17 \%$ reduction compared to pre-pandemic contact levels, results in COVID-related admissions exceeding $20 \%$ of pre-pandemic critical care capacity by late October, leading to cancellation of elective surgeries and other non-COVID health services. At high levels of vaccination and relatively high levels of mask wearing, a moderate additional effort to reduce contacts (30\% reduction compared to pre-pandemic contact levels), is necessary to avoid re-instating intensive public health measures. Compared to prior waves, the age distribution of both cases and hospitalizations shifts younger and the estimated number of pediatric critical care hospitalizations may substantially exceed $20 \%$ of capacity.

Discussion: High rates of vaccination coverage in people over the age of 12 and mask wearing in public settings will not be sufficient to prevent an overwhelming resurgence of COVID-19 in the Fall of 2021. Our analysis indicates that immediate moderate public health measures can prevent the necessity for more intense and disruptive measures later. 


\section{INTRODUCTION}

Each successive wave of the COVID-19 pandemic raises different public health challenges. In Ontario, Canada, a significant $3^{\text {rd }}$ wave in the spring of 2021, driven by the Alpha variant, led to an extended stayat-home order and closure of schools [1]. Concurrent with a large vaccination campaign, gradual release of restrictions has kept the incidence rate low through the summer. However, the more infectious and more severe Delta variant has become the dominant strain circulating across Ontario and cases are increasing $[2,3]$.

In other regions, including those with similarly high rates of vaccination, the Delta variant has led to rapidly increasing cases and significant pressure on health system resources [4-8]. Unique to this current wave is the lower average age of hospitalized patients [8-10], explained by a combination of factors including increased transmissibility and disease severity of the Delta variant [7, 11-16] paired with generally high vaccine coverage rates in older adults and hence protection from severe disease [14, 1723], lower vaccine coverage in younger adults, and the ineligibility of children under 12 years for vaccination $[2,3]$.

The goal of this study was to project the number of COVID-19 cases and demand for acute hospital resources for Fall of 2021 in a mid-sized community in southwestern Ontario (City of London and Middlesex County), with an approximate population of 500,000 . We sought to evaluate whether current levels of vaccine coverage and contact reduction could mitigate a potential $4^{\text {th }}$ wave, or whether reinstitution of more intense public health measures is required. Specifically, we evaluated public health interventions in the context of the resumption of in-person K-12 and post-secondary education. 


\section{METHODS}

We extended a previously developed deterministic dynamic compartmental model of SARS-CoV-2 transmission that predicts health outcomes and resource use in a representative mid-sized city with a full-time population of 500,000 and an additional part-time academic year population of 50,000 postsecondary students [24]. We estimated model parameters, including the duration of time spent in each health state, the infectiousness of COVID-19, the probability of needing general and specialized hospital resources, COVID-19-associated mortality, the effectiveness of COVID-19 public health measures, and the effectiveness of vaccination using the peer-reviewed literature, pre-published reports, government reports, and expert opinion. Details about the model structure, implementation, and parameterization are provided in the Supplemental Material.

Scenarios presented throughout the analysis vary in the level of contact reduction compared to the prepandemic number of close contacts. We performed sensitivity analysis to explore the impact of parameter uncertainty on model projections.

\section{Model structure}

The modelled population is divided into compartments based on age (0-4 years, 5-11 years, 12-17 years, 18-24 years, 25-49 years, 50-59 years, $60-69$ years, and $70+$ years) or by the primary setting of contacts (Post-secondary students and Long-term care (LTC) residents). A schematic of the COVID-19 health states is presented in FIGURE 1. In the model, susceptible individuals (vaccinated and unvaccinated) may become infected through interaction with infected individuals who may or may not be aware of their infection status. Infection has a pre-symptomatic phase in which an infected individual can transmit the infection to others [25-27]. Individuals may become aware of their infection status through symptombased surveillance or contact tracing. Individuals aware of their infection status with mild or moderate symptoms may isolate at home reducing their contacts by $90 \%$. Some patients develop severe 
symptoms requiring hospitalization or critical illness requiring admission to an intensive care unit (ICU).

In the model, only hospitalized patients and LTC residents die of COVID-19 infection.

\section{Impact of Variants of Concern}

We estimated the prevalence of the Alpha (B.1.1.7) and Delta (B.1.617.2) variants in the community using Ontario public health surveillance reports [2] (APPENDIX FIGURE 1). We assumed the Alpha variant to be 1.5 times more infectious than the original strain dominant in North America in the spring of $2020[16,28,29]$ and the Delta variant to be 1.5 times more infectious than Alpha $[15,16]$. In addition, we assumed the overall probability of hospitalization is 1.63 times higher for infection with the Alpha variant $[13,30,31]$, compared to the original strain, and an additional 1.85 times higher for infection with the Delta variant compared to Alpha [11-13].

\section{Contact mixing patterns}

Age-specific contact mixing patterns were estimated using the POLYMOD study, adjusted to reflect the network structure of the Canadian population [32]. Additionally, we estimated children's incremental school-based contacts using studies that used wireless sensor technologies to measure close contacts in schools $[33,34]$. We included two special populations in the model, post-secondary students, whose contacts were estimated using a survey of university students [35], and LTC residents, whose contacts were estimated using wireless sensor technology in a Canadian long-term care facility [36, 37].

\section{Dynamic behaviour change in response to COVID-19 activity in the community}

In some scenarios, we consider the impact of dynamic behaviour in response to COVID-19 outcomes in the community. These changes in behaviour are intended to capture individual decision making in the 
absence of or in advance of government intervention (e.g., reducing social contacts), such as those observed in a U.S. study [38], as well as policy changes that may be instituted in the community (e.g., capacity limits on retail services, stay-at-home orders). In the base case, we assumed that the community begins increasing the level of contact reduction by $0.75 \%$ per day once 7 ICU beds are occupied ( $10 \%$ of pre-pandemic capacity), and by an additional $1.5 \%$ per day after there have been 5 COVID-19 deaths in the past 10 days. The maximum level of contact reduction was set to $50 \%$ in adults and $70 \%$ in children and teenagers, representing, on the higher end of this range, the closure of schools.

\section{Masks}

We assume children under 12 years of age, LTC residents, and 'high-intensity physical distancers' (75\% of the population) wear masks for $86 \%$ of their contacts and that the remainder ('low-intensity physical distancers') wear masks for $38 \%$ of their contacts consistent with reported levels of mask wearing in a survey of Canadians [39]. We assume that as people become fully vaccinated, they reduce their mask wearing to $38 \%$ of their contacts. We assume cloth masks reduce the probability of disease transmission by $46 \%$ based on the reduction in transmission observed in German cities after the introduction of a mask mandate [40].

\section{Vaccination uptake and effectiveness}

We implemented first and second dose uptake using actual age-specific weekly vaccination data published by the local health unit until the week of August 15, 2021 and estimate forward using a decreasing weekly rate of uptake (APPENDIX FIGURE 2).

In the base case, we assumed that full vaccination reduces the probability of infection by the Alpha variant by $90 \%[18,41-45]$ and by the Delta variant by $76.5 \%$ (15\% less than Alpha) $[18,23,46]$. To avoid 
medRxiv preprint doi: https://doi.org/10.1101/2021.09.02.21263000; this version posted September 5, 2021. The copyright holder for this preprint

(which was not certified by peer review) is the author/funder, who has granted medRxiv a license to display the preprint in perpetuity.

It is made available under a CC-BY-ND 4.0 International license .

double counting the benefit already conferred from the reduced risk of infection, we calculate the risk reduction for symptomatic disease and the risk reduction of hospitalization conditional on infection. This led us to assume a $45 \%$ reduction in the probability of symptomatic infection and a $60 \%$ reduction in the risk of hospitalization conditional on infection in vaccinated individuals. Cumulatively, through both the prevention of infections and reduced disease severity, in the model, vaccination reduces hospitalizations by $96 \%$ against the Alpha variant and $91 \%$ against the Delta variant, consistent with population level estimates of vaccine effectiveness [18-23, 44, 47]. 


\section{RESULTS}

\section{Base case projections}

Ontario entered Step 3 of the Wave 3 recovery plan on July 16, $2021[48,49]$. We estimate the average level of contact reduction in Step 3 to be 17\%, compared to pre-pandemic numbers of daily close contacts, via model calibration to diagnosed cases, hospitalizations, and deaths to August 25, 2021 (APPENDIX FIGURE 3). From August 25, 2021, onwards, we predict the number of new infections per day, ward bed occupancy, and ICU bed occupancy under different levels of contact reduction. At all levels of contact reduction, the number of new infections per day increases upon commencement of inperson schools and post-secondary education. When the level of contact reduction is between $15 \%$ and $20 \%$, similar to the level of contact reduction estimated for August 2021, the number of infections per day exceeds 40 per 100,000 in late September. In contrast, at levels of contact reduction between $25 \%$ and $27.5 \%$, the number of infections per day exceeds 40 per 100,000 nearly a month later, in midOctober to early-November. Correspondingly, ICU occupancy exceeds 15 COVID-19 patients (representing $20 \%$ of pre-pandemic capacity), the level at which elective surgeries and other procedures must be cancelled, in late October, mid-November, or early December for scenarios with contact reductions of $20 \%, 25 \%$, and $27 \%$ relative to pre-pandemic average daily close contacts (FIGURE 2 ).

We assumed that individuals change their contact behaviours and policy-makers will reinstitute restrictive public health measures to reduce contacts in response to worsening COVID-19 outcomes in the community. In the base case analysis, we assumed that contact reduction would begin to increase after 7 ICU beds were occupied with COVID-19 patients (representing 10\% of pre-COVID capacity) and, more intensely, when there were 5 COVID-19 deaths within 10 days in the community. In scenarios with $15 \%, 20 \%$, and $25 \%$ contact reduction, the ICU threshold, of 7 beds, was exceeded October $12^{\text {th }}$, October $18^{\text {th }}$, and November $3^{\text {rd }}$ respectively, and the number of COVID-19 deaths exceeded the threshold of 5 COVID-19 deaths in the past 10 days approximately two weeks later (APPENDIX TABLE 5). 
Initiating a higher contact reduction earlier is associated with lower peak ICU and ward bed occupancies, even when the threshold to begin increasing contact reductions is the same (FIGURE 2). In the scenarios maintaining between a $15 \%$ and $20 \%$ contact reduction compared to pre-pandemic levels of daily contacts (i.e., similar to Step 3), peak ICU occupancy was between 26 and 34 beds and peak ward bed occupancy was between 78 and 102 beds. Increasing the level of general population contact reduction to between $25 \%$ and $27 \%$, led to both a later need for restrictive policies and lower peak hospitalizations. Increasing the level of contact reduction to $30 \%$, compared to pre-pandemic levels of daily contacts, prevented the need for more restrictive policies. The scenario in which contacts were reduced $30 \%$ was the only scenario to mitigate the $4^{\text {th }}$ wave such that peak hospital occupancy remained below the peak of the $3^{\text {rd }}$ wave.

\section{Age distribution of infections and hospitalizations}

Compared to previous pandemic waves, children under 12 years compose a greater number and fraction of projected infections and hospitalizations (FIGURE 3). In scenarios with and without dynamic behaviour and policy change, children under 12 years represent between $24 \%$ and $31 \%$ of projected infections between August 1 and December 31, 2021. Infected children are less likely to develop severe disease and are less likely to be hospitalized. As a result, they represent between $6.0 \%$ and $8.5 \%$ of ward hospitalizations and 3.2\% and $4.6 \%$ of ICU hospitalizations. Despite their relatively low rate of severe disease requiring hospitalization, without policy intervention to reduce contacts in the community, the projected peak pediatric ICU occupancy is $3.4,2.6$, and 1.4 for scenarios with $15 \%, 20 \%$, and $25 \%$ contact reduction, respectively (compared to a total capacity of 12 pediatric ICU beds for COVID-19 and non-COVID-19 patients) (APPENDIX TABLE 5). 
University and college students are mandated to be vaccinated [50], and so we assume that $98 \%$ of the student population will be vaccinated. Even so, in scenarios with low levels of contact reduction, $15 \%$, $20 \%$, and $25 \%$, we estimate that $23 \%, 14 \%$, and $5.4 \%$ of the student population, respectively, would become infected over the term without additional mitigation. In scenarios with higher levels of contact reduction, $27 \%$ and $30 \%$, and in all cases in which public health measures are reinstituted, the proportion of students infected over the term is less than $4 \%$. Consistent across all scenarios is the connection between on-campus infections and increased community transmission with, on average, each infection in a post-secondary student leading to 0.2 secondary infections in the off-campus community.

\section{Timing of higher-intensity policy restrictions}

Immediately increasing the intensity of policy restrictions to a moderate level of contact reduction, i.e., $27.5 \%$ to $30 \%$ compared to pre-pandemic levels, can prevent the further need to re-instate highintensity policies intended to reduce illness and protect hospital resources.

At current levels of contact reduction, re-instatement of high-intensity policy restrictions, such as a stayat-home order, will be required in the fall of 2021. The timing at which higher-intensity contact reduction efforts begin affects COVID-19 community outcomes. Conditional on the initial level of contact reduction, initiating higher-intensity policies earlier rather than later lowers peak hospital occupancy

(FIGURE 4). Importantly, the same set of trigger thresholds leads to greater peak occupancy at lower levels of initial contact reduction. Because hospital occupancy information lags infections, at lower initial levels of contact reduction (e.g., $15 \%$ to $20 \%$ ), there are more infections already in the community when the threshold is achieved, leading to higher levels of peak occupancy (FIGURE 4 and APPENDIX TABLE 5). 
medRxiv preprint doi: https://doi.org/10.1101/2021.09.02.21263000; this version posted September 5, 2021. The copyright holder for this preprint

(which was not certified by peer review) is the author/funder, who has granted medRxiv a license to display the preprint in perpetuity.

It is made available under a CC-BY-ND 4.0 International license .

\section{Sensitivity analysis}

Many of our model parameters, in particular those that are specific to the Delta variant, are highly uncertain warranting extensive sensitivity analysis. We highlight those that meaningfully impact the policy analysis.

Vaccine effectiveness against infection by the Delta variant: The relative performance of vaccines in preventing infection by the Delta variant has been empirically measured in only a few studies to date $[18,44,46,51]$. In our base case analysis, we assumed that a fully vaccinated person is $90 \%$ less likely to be infected by the Alpha variant than an unvaccinated person and that vaccines provide $15 \%$ less, i.e., 76.5\%, protection against infection with the Delta variant. In sensitivity analysis we considered scenarios in which vaccines provide $80 \%$ and $85 \%$ protection against infection by the Delta variant. Higher vaccine efficacy is associated with lower numbers of infections and a delayed need for high-intensity policy restrictions. However, even with the most optimistic vaccine effectiveness against the Delta variant, completely averting the need for high-intensity policy restrictions was only possible in scenarios in which the initial level of contact reduction exceeded 20\% (APPENDIX FIGURE 4).

Projected vaccine uptake: In the base case, we assumed observed vaccine uptake until the week of August 15, and then projected forward based on a slowing weekly rate of uptake (APPENDIX FIGURE 2). In sensitivity analysis, we considered alternative projections in which at least $85 \%, 90 \%$, or $95 \%$ were vaccinated in each vaccine-eligible age group. Even 95\% vaccination in all eligible age groups did not prevent the necessity of high-intensity restrictions from being re-imposed without initial contact reductions exceeding 27\% (APPENDIX FIGURE 6).

Pediatric length of stay: Until recently, pediatric patients were a small fraction of all hospitalized patients and so there is greater uncertainty around their hospital length of stay and outcomes. In the base case, we estimated pediatric hospital and ICU length of stay based on moderately sized patient 
medRxiv preprint doi: https://doi.org/10.1101/2021.09.02.21263000; this version posted September 5, 2021. The copyright holder for this preprint

(which was not certified by peer review) is the author/funder, who has granted medRxiv a license to display the preprint in perpetuity.

It is made available under a CC-BY-ND 4.0 International license .

cohorts [52-54]. In sensitivity analysis we considered a +1 day and +2 day increase to both pediatric ward and critical care hospitalizations. Given the small absolute number of pediatric critical care beds available in our Centre (12 beds) and the true catchment area of the pediatric hospital being four times greater than the modelled population, longer length of stay has the ability to meaningfully impact peak occupancy (approximately a 33\% increase) (APPENDIX TABLE 6). 


\section{DISCUSSION}

With increased transmissibility, increased severity, and potentially lower vaccine protection against infection, the Delta variant has changed the nature of the pandemic $[7,11-16,23,44]$. It is no longer conceivable to rely on high rates of vaccination in people over the age of 12 years to prevent an overwhelming resurgence of COVID-19 in the Fall of 2021. Our analysis found that at high levels of vaccination and relatively high levels of mask wearing, a moderate additional effort to reduce contacts is necessary to avoid re-instating intensive public health measures. Maintaining contact reductions at the current level, estimated to be a $17 \%$ reduction compared to pre-pandemic contact levels, results in exceeding $20 \%$ of pre-pandemic ICU capacity by late October, requiring cancellation of elective surgeries. Increasing the contact reduction level to $25 \%$ results in exceeding $20 \%$ of ICU capacity in the third week of November. Reducing contacts by $27 \%$ to $30 \%$, compared to pre-pandemic contact levels, prevents high case volumes and the re-instatement of more restrictive public health measures.

Highly effective vaccination has fundamentally decreased the severity of disease and provides substantial protection against infection, markedly slowing disease transmission [17-21, 46, 47, 51, 55]. Vaccination rates across Canada are among the highest coverage rates in the world [56]. While still highly effective at preventing severe disease against the Delta variant, further increasing vaccination rates among the vaccine-eligible population is not sufficient to mitigate a fourth wave. Policies to achieve an overall $30 \%$ contact reduction include maintaining firm limits on indoor gathering size, facilitating work from home, and providing paid sick leave to support quarantine and isolation. Although not specifically considered in our analysis, other measures that have been proposed include frequent testing in school settings and workplaces where physical distancing is not possible [57-62]. 
Our projections are consistent with other modelling projections. For example, without additional contact reduction and without responsive behaviour change, we estimate $50 \%$ to $60 \%$ of children under 17 years will become infected over the fall term, consistent with an analysis of school-based transmission that estimated $50 \%$ of susceptible children would become infected at school over the fall term with universal masking and low-levels (30\%) of vaccine protection [63]. We estimate that a $25 \%$ contact reduction leads to approximately $5.4 \%$ of the post-secondary student population becoming infected over the term, even with a $98 \%$ vaccination rate, consistent with the projection from a model of COVID-19 transmission on college campuses [61]. In addition, three models providing population-level projections for the fall of 2021 in Canada, two at the national level and another for British Columbia, demonstrate a similar relative increase in the number of infections per day compared to the $3^{\text {rd }}$ wave as well as a similar shift in the age distribution of infections towards younger people [64-66].

In-person education is an essential priority for the overall wellbeing, psychosocial development, and educational development of children $[1,67,68]$, but it also increases the absolute number of contacts for children. School-based policies such as student cohorts, small class sizes, improved ventilation, routine testing, and vaccine mandates for teachers and staff can reduce in-school transmission $[68,69]$. Even so, schools will remain higher contact environments where, particularly in elementary schools where children are unvaccinated, significant outbreaks are possible [69-71]. Ultimately, in order for children to return to in-person education and minimize the impact of increased contacts on community transmission, adults in the community will need to further reduce their contacts.

Our study has several limitations. First, in the Canadian healthcare system, no region is entirely selfcontained. During wave 3, patients were transferred for ICU and hospital care between cities, regions, 
and provinces. In addition, pediatric hospital resources are organized differently from adult resources, the catchment area for the former being approximately three times the size of the latter. Second, our triggers for behaviour and policy change were set around total critical care occupancy, driven largely by adult use; at a $30 \%$ contact reduction, peak pediatric ICU demand was 0.07 per 100,000 population (representing 1.4 pediatric ICU beds adjusting for the catchment population of 2 million for the pediatric hospital), which still exceeds $10 \%$ of capacity. Higher rates of infection in children may lead to more rapid adoption of behaviour change, but the lower relative capacity in pediatric critical care will require policy makers to respond to rates of utilization in pediatric facilities specifically. Third, our model does not incorporate waning vaccine efficacy. While $65 \%$ of the vaccinated population was vaccinated after April 1 (within the past 4 months), our model may underestimate infection risk and disease severity in the older adult population because $75 \%$ of people over the age of 70 years and almost all long-term care residents were vaccinated more than 4 months ago [2, 3]. Finally, we do not consider seasonality or a transition towards indoor contacts as the weather gets colder. In all these regards, our projections can be considered conservative.

The $R_{0}$ of the Delta variant is between 6.75 and 8.0. Notwithstanding high rates of vaccine coverage among the vaccine-eligible ( $76 \%$ fully vaccinated and $83 \%$ having at least first dose [3]), approximately $15 \%$ of the total population remains ineligible for vaccination heading into the fall of 2021 because they are under 12 years of age. Ongoing mask wearing and reducing contacts by, on average, $30 \%$ is required to prevent re-instatement of restrictive policies as hospital resources, again, become overwhelmed. Our analysis indicates that immediate moderate public health measures can prevent the necessity for more intense, disruptive, and difficult to sustain measures later. 
medRxiv preprint doi: https://doi.org/10.1101/2021.09.02.21263000; this version posted September 5, 2021. The copyright holder for this preprint (which was not certified by peer review) is the author/funder, who has granted medRxiv a license to display the preprint in perpetuity.

It is made available under a CC-BY-ND 4.0 International license .

Figure 1. Model schematic

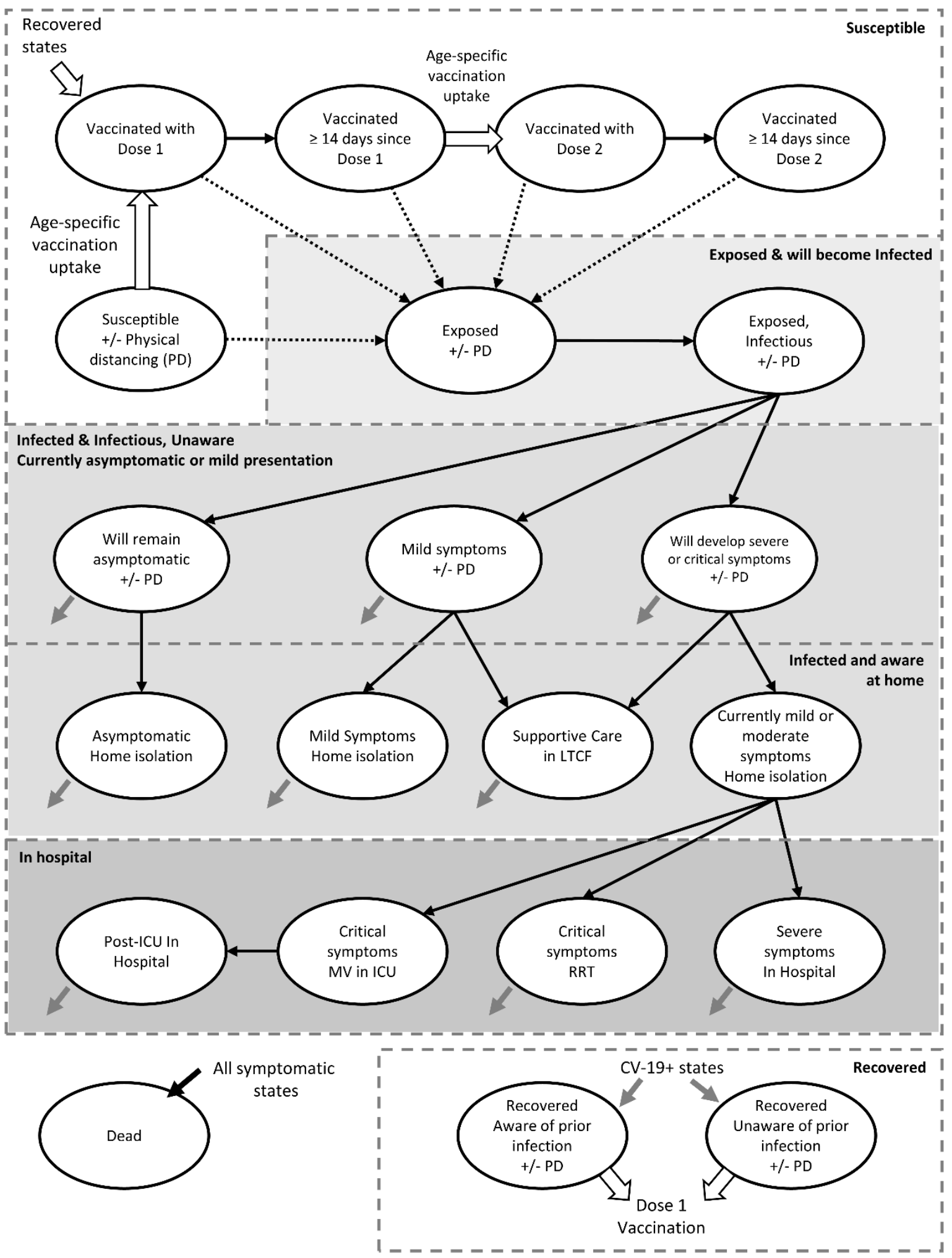


medRxiv preprint doi: https://doi.org/10.1101/2021.09.02.21263000; this version posted September 5, 2021. The copyright holder for this preprint (which was not certified by peer review) is the author/funder, who has granted medRxiv a license to display the preprint in perpetuity.

It is made available under a CC-BY-ND 4.0 International license.

Figure 2. Projected (A) new infections per day, (B) ICU occupancy, and (C) ward bed occupancy for August 2021 through December 2021 in London-Middlesex in and from members of the local community without (dashed lines) and with (solid lines) incorporating individual-level behaviour change and the re-instatement of restrictive physical distancing policies and business closures. In these scenarios, behaviours and policies begin to change when the ICU occupancy reaches 7 people ( $10 \%$ of pre-COVID capacity) or there have been at least 5 COVID-19 deaths in 10 days.

(A)

New Infections per Day (pop. 500,000)

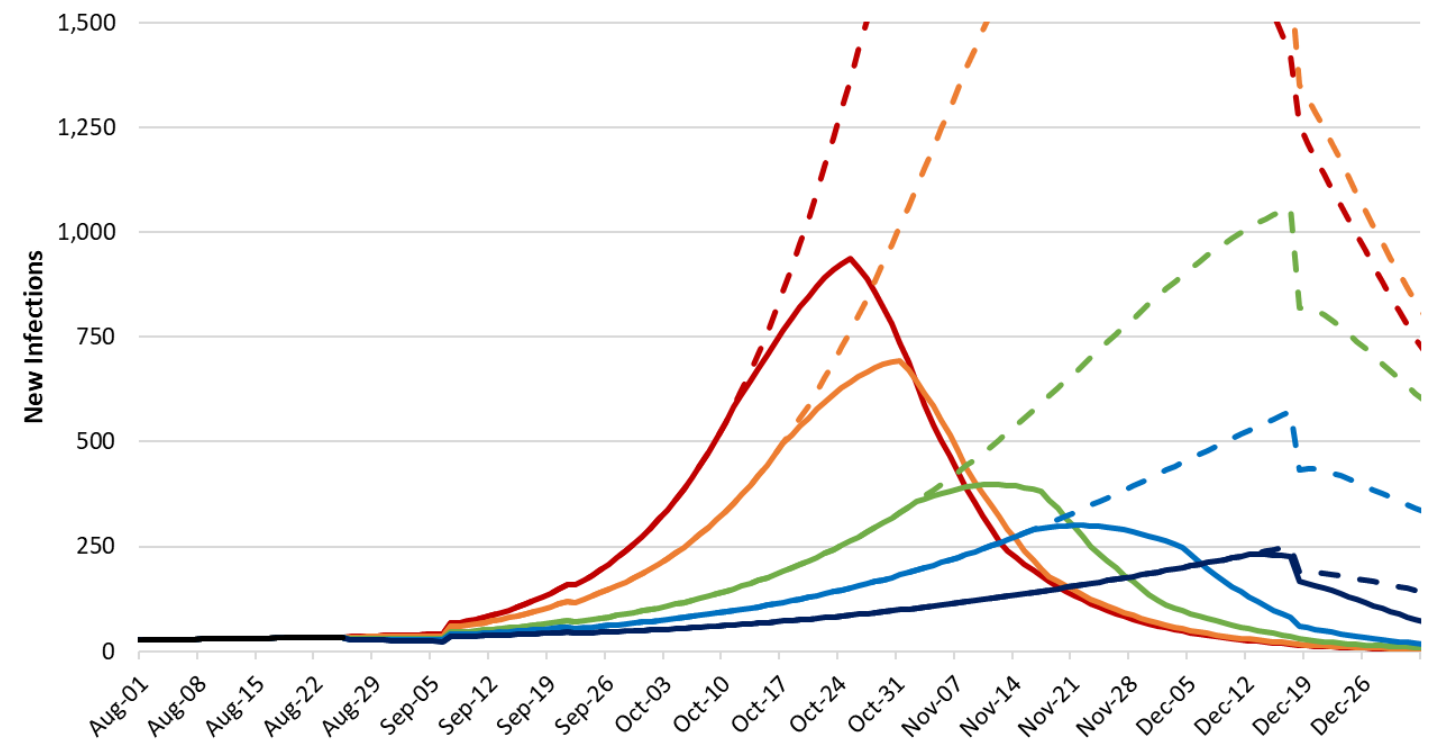

(B)

ICU Bed Occupancy (pop. 500,000)

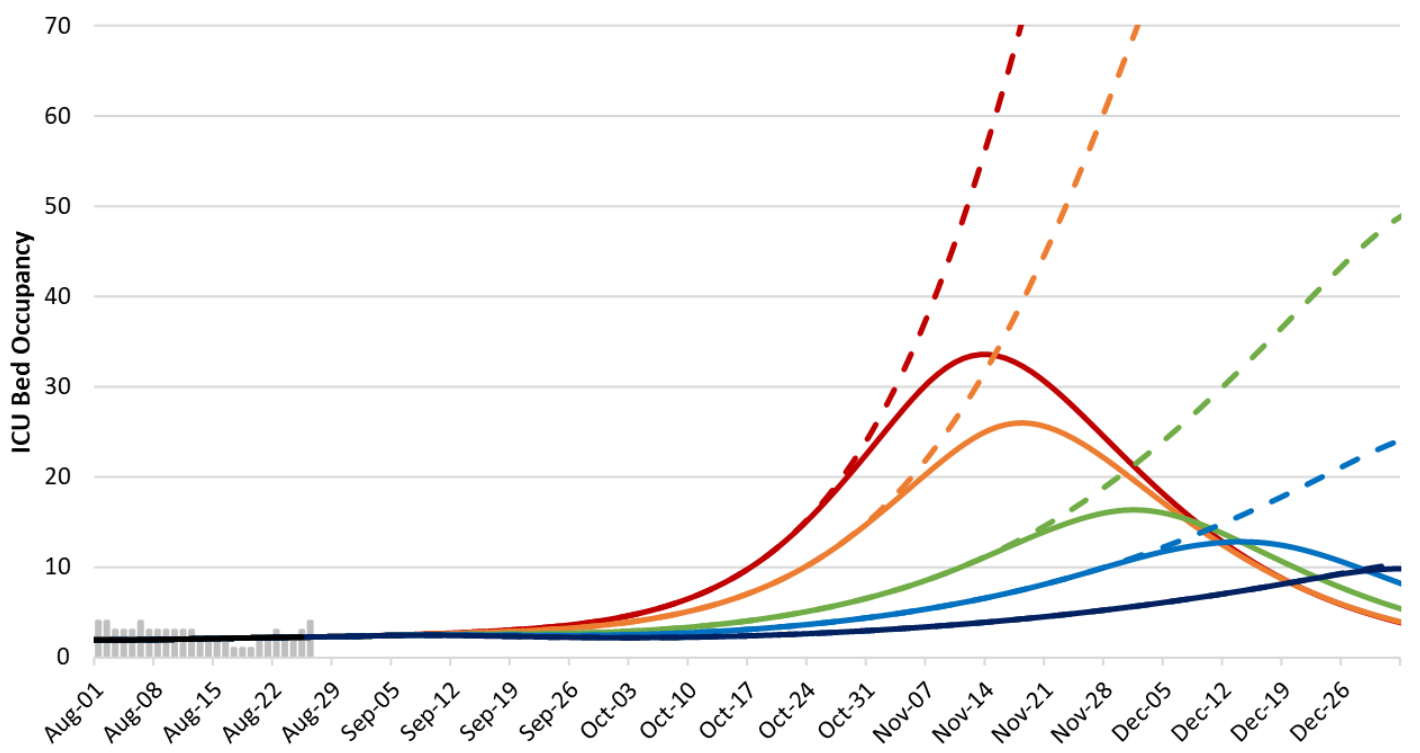


(C)

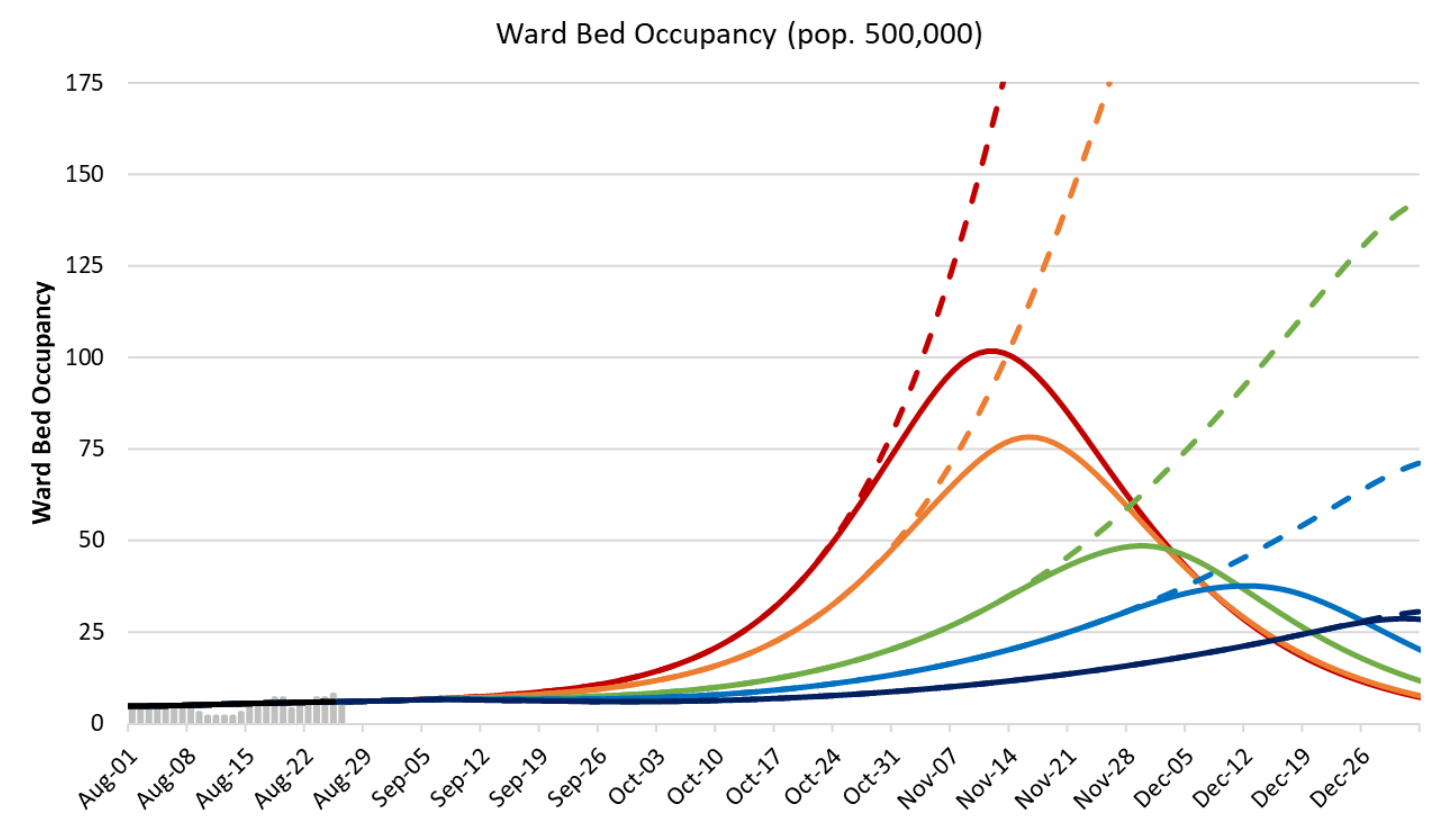

$-15 \%$ contact reduction

$-20 \%$ contact reduction

$-25 \%$ contact reduction

$-27 \%$ contact reduction

- $30 \%$ contact reduction

Modelled to August 25

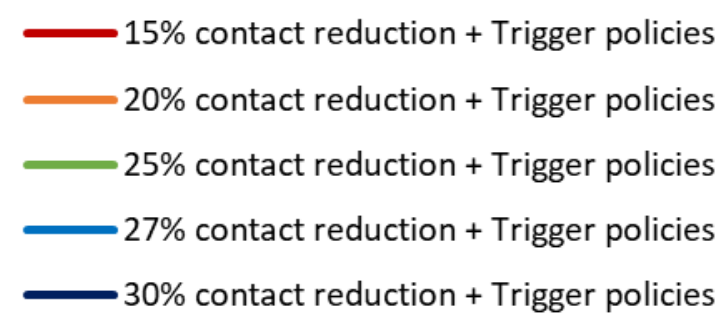

$15 \%$ contact reduction + Trigger policies $20 \%$ contact reduction + Trigger policies $5 \%$ contact reduction + Trigger policies $30 \%$ contact reduction + Trigger policies 
medRxiv preprint doi: https://doi.org/10.1101/2021.09.02.21263000; this version posted September 5, 2021. The copyright holder for this preprint (which was not certified by peer review) is the author/funder, who has granted medRxiv a license to display the preprint in perpetuity.

It is made available under a CC-BY-ND 4.0 International license.

Figure 3. Modelled age distribution of (A) new infections per day, (B) ICU occupancy, and (C) ward bed occupancy for September 2020 through December 2021 in London-Middlesex in and from members of the local community. The scenario shown assumed a $25 \%$ contact reduction and no dynamic behaviour change or policy change.

(A)

New Infections per Day (pop. 500,000) by age

1500

1250

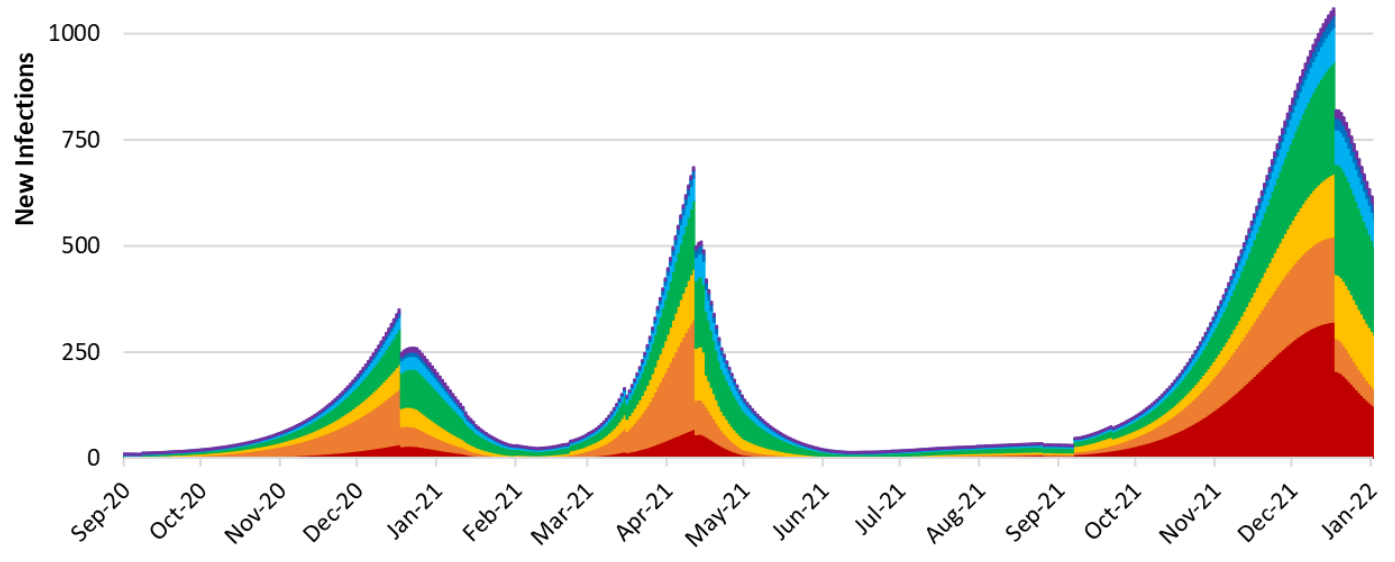

(B)

ICU Bed Occupancy (pop. 500,000) by age

70

60

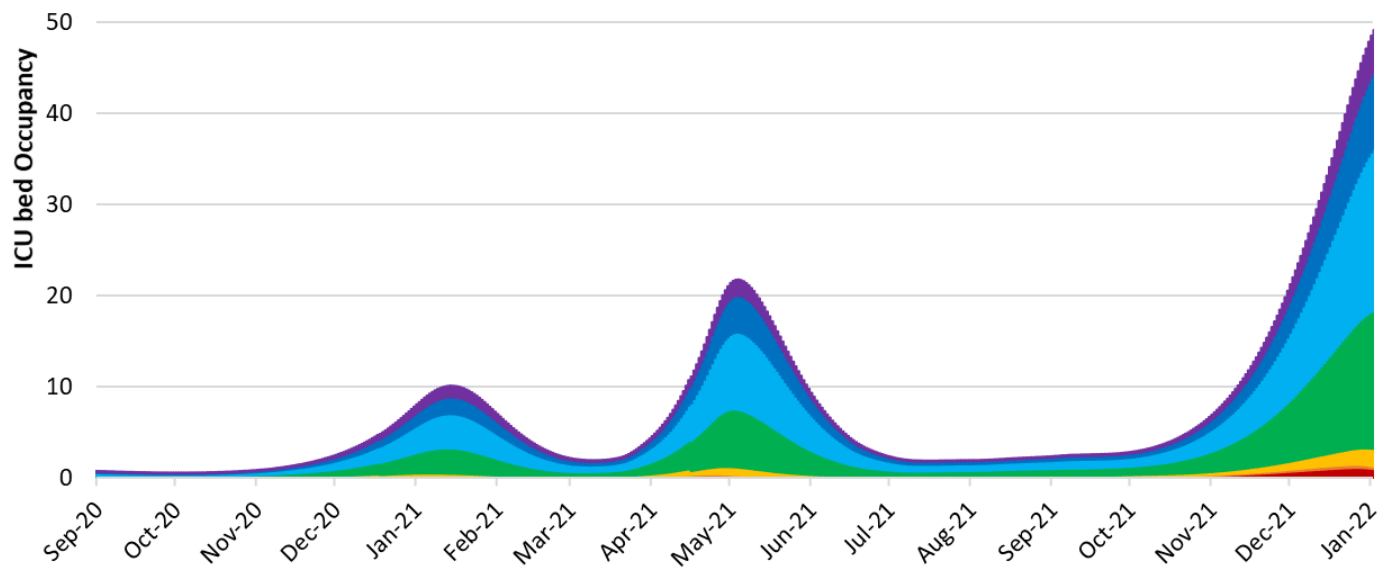

(C) 
medRxiv preprint doi: https://doi.org/10.1101/2021.09.02.21263000; this version posted September 5, 2021. The copyright holder for this preprint (which was not certified by peer review) is the author/funder, who has granted medRxiv a license to display the preprint in perpetuity.

It is made available under a CC-BY-ND 4.0 International license.

Ward Bed Occupancy per Day (pop. 500,000) by age

175

150

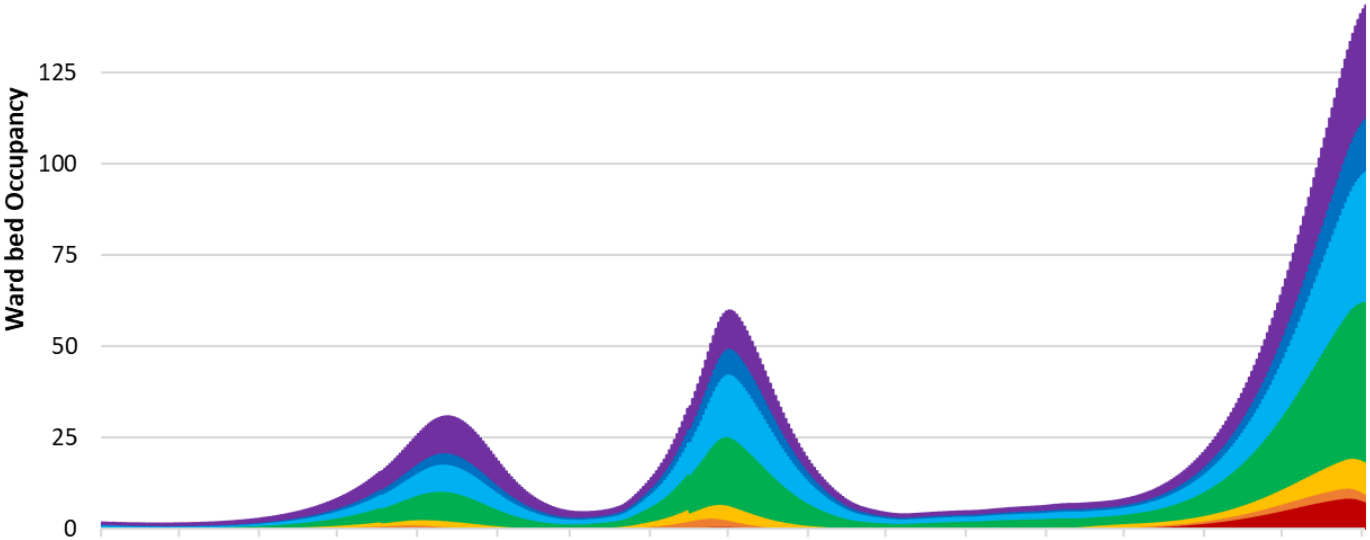

0

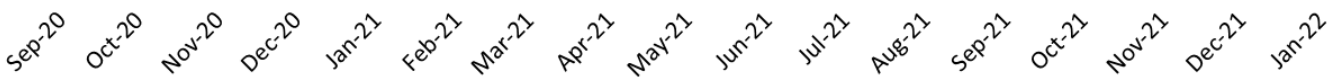

- Under 12

$18-24$

50-59
12-17

$\square$ 25-49

60-69

- Over 70 and LTC 
medRxiv preprint doi: https://doi.org/10.1101/2021.09.02.21263000; this version posted September 5, 2021. The copyright holder for this preprint (which was not certified by peer review) is the author/funder, who has granted medRxiv a license to display the preprint in perpetuity.

It is made available under a CC-BY-ND 4.0 International license.

Figure 4. Modelled age distribution of (A) ICU occupancy, and (B) ward bed occupancy for September 2020 through December 2021 in London-Middlesex in and from members of the local community. The scenario shown vary in the level of contact reduction at baseline (15\% red; $20 \%$ orange; $25 \%$ green) and the thresholds used for dynamic behaviour and policy changes: no response, long-dashed line (shown for reference); later response thresholds (10 ICU beds and 7 COVID-19 deaths in 10 days, short-dash line); base case response thresholds (7 ICU beds and 5 COVID-19 deaths in 10 days, solid line); and, earlier response thresholds (5 ICU beds and 3 COVID-19 deaths in 10 days).

(A)

ICU Bed Occupancy (pop. 500,000)

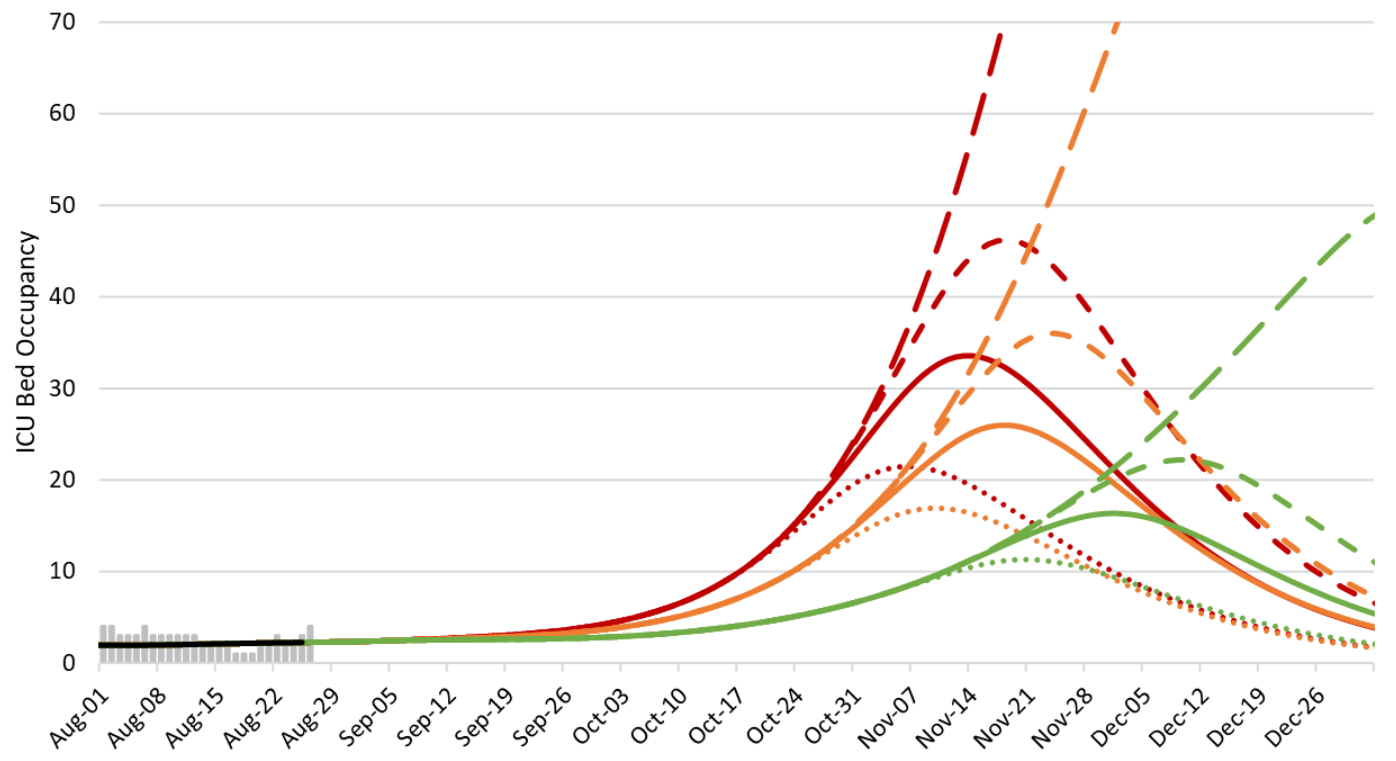


medRxiv preprint doi: https://doi.org/10.1101/2021.09.02.21263000; this version posted September 5, 2021. The copyright holder for this preprint (which was not certified by peer review) is the author/funder, who has granted medRxiv a license to display the preprint in perpetuity.

It is made available under a CC-BY-ND 4.0 International license .

(B)

Ward Bed Occupancy (pop. 500,000)

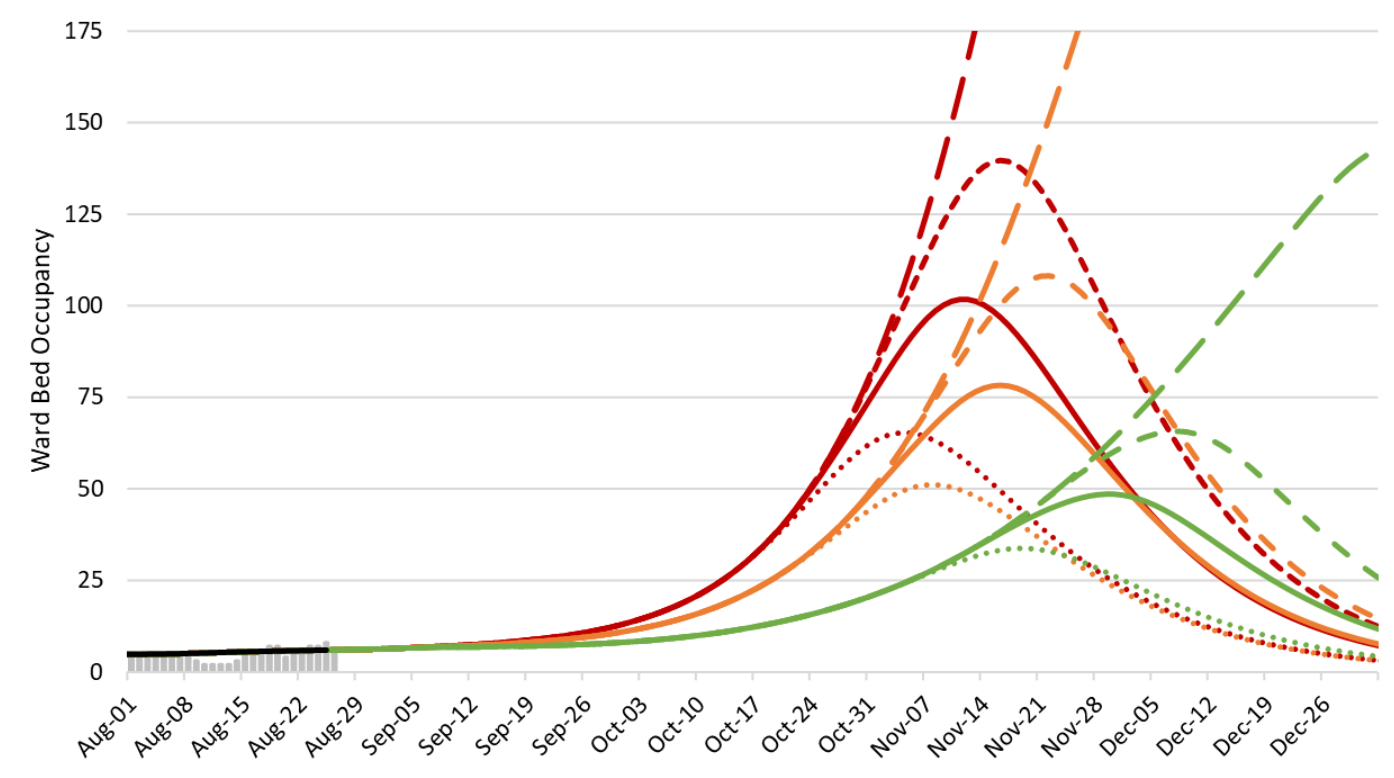

- $15 \%$ contact reduction $20 \%$ contact reduction $25 \%$ contact reduction - Modelled to Agust 25

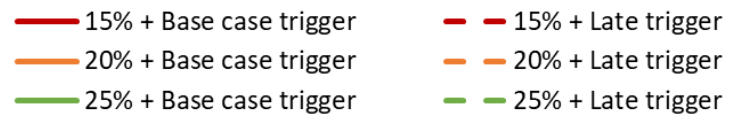

$-15 \%+$ Late trigger
$--20 \%+$ Late trigger

$--25 \%+$ Late trigger $\cdots . .15 \%+$ Early trigger

$\ldots . .20 \%+$ Early trigger

$\ldots . .25 \%+$ Early trigger 


\section{REFERENCES}

1. Gallagher-Mackay K, Srivastava P, Underwood K, Dhuey E, McCready L, Born K, et al. COVID-19 and Education Disruption in Ontario: Emerging Evidence on Impacts. COVID-19 Science Advisory Table for Ontario. June 4, 2021.

2. Public Health Ontario. COVID-19 Data and Surveillance. (Available at: https://www.publichealthontario.ca/en/data-and-analysis/infectious-disease/covid-19-datasurveillance).

3. Middlesex-London Health Unit. Summary of COVID-19 cases in Middlesex-London. Available at: https://www.healthunit.com/covid-19-cases-middlesex-london.

4. Mahase E. Delta variant: What is happening with transmission, hospital admissions, and restrictions? BMJ. 2021;373:n1513. doi: 10.1136/bmj.n1513.

5. Wadman M. A grim warning from Israel: Vaccination blunts, but does not defeat Delta. Science (August 16, 2021). Available at: https://www.sciencemag.org/news/2021/08/grim-warning-israelvaccination-blunts-does-not-defeat-delta.

6 . Thebault R. Iceland has been a vaccination success. Why is it seeing a coronavirus surge? The Washington Post (August 15, 2021) Available at:

https://www.washingtonpost.com/world/europe/iceland-covid-surge-vaccines/2021/08/14/bdd88d04fabd-11eb-911c-524bc8b68f17 story.html.

7. Riley $\mathrm{S}$, Wang $\mathrm{H}$, Eales $\mathrm{O}$, Haw D, Walters $\mathrm{CE}$, Ainslie KEC, et al. REACT-1 round 12 report: resurgence of SARS-CoV-2 infections in England associated with increased frequency of the Delta variant. medRxiv. 2021:2021.06.17.21259103. doi: 10.1101/2021.06.17.21259103.

8. Wise J. Covid-19: Exponential growth in infections in England is driven by young people. BMJ. 2021;373:n1568. doi: 10.1136/bmj.n1568.

9. Borter G. Children hospitalized with COVID-19 in U.S. hits record number (August 16, 2021). Reuters. Available at: https://www.reuters.com/world/us/children-hospitalized-with-covid-19-us-hitsrecord-number-2021-08-14/.

10. Office for National Statistics. Coronavirus (COVID-19) latest insights: Hospitals (August 27, 2021) [Accessed August 30, 2021] Available at:

https://www.ons.gov.uk/peoplepopulationandcommunity/healthandsocialcare/conditionsanddiseases/ articles/coronaviruscovid19latestinsights/hospitals.

11. Twohig KA, Nyberg T, Zaidi A, Thelwall S, Sinnathamby MA, Aliabadi S, et al. Hospital admission and emergency care attendance risk for SARS-CoV-2 delta (B.1.617.2) compared with alpha (B.1.1.7) variants of concern: a cohort study. The Lancet Infectious Diseases. doi: 10.1016/S1473-3099(21)004758.

12. Sheikh A, McMenamin J, Taylor B, Robertson C, Public Health S, the EIIC. SARS-CoV-2 Delta VOC in Scotland: demographics, risk of hospital admission, and vaccine effectiveness. Lancet.

2021;397(10293):2461-2.

13. Fisman DN, Tuite AR. Progressive Increase in Virulence of Novel SARS-CoV-2 Variants in Ontario, Canada. medRxiv. 2021:2021.07.05.21260050. doi: 10.1101/2021.07.05.21260050.

14. Reardon S. How the Delta variant achieves its ultrafast spread. Nature news. 2021;([Accessed August 14, 2021] Available at: https://doi.org/10.1038/d41586-021-01986-w).

15. Scientific Pandemic Influenza Group on Modelling Operational sub-group (SPI-M-O). Consensus Statement on COVID-19 (June 2, 2021).

16. Yang W, Shaman J. Epidemiological characteristics of three SARS-CoV-2 variants of concern and implications for future COVID-19 pandemic outcomes. medRxiv. 2021:2021.05.19.21257476.

17. COVID-19 vaccine surveillance report: Week 33 (August 19, 2021). Public Health England. Available at: https://www.gov.uk/government/publications/covid-19-vaccine-surveillance-report. 
18. Rosenberg ES, Holtgrave DR, Dorabawila V, Conroy M, Greene D, Lutterloh E, et al. New COVID19 Cases and Hospitalizations Among Adults, by Vaccination Status - New York, May 3-July 25, 2021. MMWR Morb Mortal Wkly Rep. 2021;70.

19. Pfizer-BioNTech COVID-19 vaccine (BNT162, PF-07302048). Vaccines and Related Biological Products Advisory Committee Briefing Document. December 10, 2020.

20. Polack FP, Thomas SJ, Kitchin N, Absalon J, Gurtman A, Lockhart S, et al. Safety and Efficacy of the BNT162b2 mRNA Covid-19 Vaccine. N Engl J Med. 2020;383(27):2603-15. doi: 10.1056/NEJMoa2034577. PubMed PMID: 33301246; PubMed Central PMCID: PMCPMC7745181.

21. Chung $H$, He S, Nasreen S, Sundaram ME, Buchan SA, Wilson SE, et al. Effectiveness of BNT162b2 and mRNA-1273 covid-19 vaccines against symptomatic SARS-CoV-2 infection and severe covid-19 outcomes in Ontario, Canada: test negative design study. BMJ. 2021;374:n1943.

22. Public Health England. COVID-19 vaccine surveillance report: 19 August 2021 (week 33) [Accessed August 20, 2021] Available at: https://www.gov.uk/government/publications/covid-19vaccine-surveillance-report.

23. Fowlkes A, Gaglani M, Groover K, Thiese MS, Tyner H, Ellingson K, et al. Effectiveness of COVID19 Vaccines in Preventing SARS-CoV-2 Infection Among Frontline Workers Before and During B.1.617.2 (Delta) Variant Predominance - Eight U.S. Locations, December 2020-August 2021. MMWR Morb Mortal Wkly Rep. 2021;70(34):1167-9.

24. Cipriano LE, Haddara WMR, Zaric GS, Enns EA. Impact of university re-opening on total community COVID-19 burden. PLoS One. 2021;16(8):e0255782.

25. Du Z, Wang L, Cauchemez S, Xu X, Wang X, Cowling BJ, et al. Risk for Transportation of 2019 Novel Coronavirus Disease from Wuhan to Other Cities in China. Emerg Infect Dis. 2020;26(5).

26. Tindale LC, Stockdale JE, Coombe M, Garlock ES, Lau WYV, Saraswat M, et al. Evidence for transmission of COVID-19 prior to symptom onset. Elife. 2020;9. doi: 10.7554/eLife.57149.

27. He X, Lau EHY, Wu P, Deng X, Wang J, Hao X, et al. Temporal dynamics in viral shedding and transmissibility of COVID-19. Nat Med. 2020;26:672-5.

28. Volz E, Mishra S, Chand M, Barrett JC, Johnson R, Geidelberg L, et al. Assessing transmissibility of SARS-CoV-2 lineage B.1.1.7 in England. Nature. 2021;593(7858):266-9.

29. Davies NG, Abbott S, Barnard RC, Jarvis $\mathrm{Cl}$, Kucharski AJ, Munday JD, et al. Estimated transmissibility and impact of SARS-CoV-2 lineage B.1.1.7 in England. Science. 2021;372(6538).

30. Tuite AR, Fisman DN, Odutayo A, Bobos P, Allen V, Bogoch II, et al. COVID-19 Hospitalizations, ICU Admissions and Deaths Associated with the New Variants of Concern. Ontario COVID-19 Science Advisory Table Science Brief (March 29, 2021) Available at: https://doiorg/1047326/ocsat2021021810. 31. Nyberg T, Twohig KA, Harris RJ, Seaman SR, Flannagan J, Allen $\mathrm{H}$, et al. Risk of hospital admission for patients with SARS-CoV-2 variant B.1.1.7: cohort analysis. BMJ. 2021;373:n1412.

32. Prem K, Cook AR, Jit M. Projecting social contact matrices in 152 countries using contact surveys and demographic data. PLoS Comput Biol. 2017;13(9):e1005697.

33. Stehle J, Voirin N, Barrat A, Cattuto C, Isella L, Pinton JF, et al. High-resolution measurements of face-to-face contact patterns in a primary school. PLoS One. 2011;6(8):e23176.

34. Salathe $\mathrm{M}$, Kazandjieva $\mathrm{M}$, Lee JW, Levis $\mathrm{P}$, Feldman MW, Jones JH. A high-resolution human contact network for infectious disease transmission. Proc Natl Acad Sci U S A. 2010;107(51):22020-5.

35. Beutels P, Shkedy Z, Aerts M, Van Damme P. Social mixing patterns for transmission models of close contact infections: exploring self-evaluation and diary-based data collection through a web-based interface. Epidemiol Infect. 2006;134(6):1158-66.

36. Najafi M, Laskowski M, de Boer PT, Williams E, Chit A, Moghadas SM. The Effect of Individual Movements and Interventions on the Spread of Influenza in Long-Term Care Facilities. Med Decis Making. 2017;37(8):871-81. 
37. Champredon D, Najafi M, Laskowski M, Chit A, Moghadas SM. Individual movements and contact patterns in a Canadian long-term care facility. AIMS Public Health. 2018;5(2):111-21.

38. Goolsbee A, Syverson C. Fear, Lockdown, and Diversion: Comparing Drivers of Pandemic Economic Decline 2020. National Bureau of Economic Research Working Paper Series. 2020;No. 27432. doi: $10.3386 /$ w27432.

39. Angus Reid Institute. COVID-19 Compliance: One-in-five Canadians making little to no effort to stop coronavirus spread. August 17, 2020. Available at: http://angusreid.org/covid-compliance/.

40. Mitze T, Kosfeld R, Rode J, Walde K. Face masks considerably reduce COVID-19 cases in Germany. Proc Natl Acad Sci U S A. 2020;117(51):32293-301.

41. Abu-Raddad LJ, Chemaitelly H, Butt AA, National Study Group for C-V. Effectiveness of the BNT162b2 Covid-19 Vaccine against the B.1.1.7 and B.1.351 Variants. N Engl J Med. 2021;385(2):187-9. 42. Dagan N, Barda N, Kepten E, Miron O, Perchik S, Katz MA, et al. BNT162b2 mRNA Covid-19 Vaccine in a Nationwide Mass Vaccination Setting. N Engl J Med. 2021;384(15):1412-23.

43. Pawlowski C, Lenehan P, Puranik A, Agarwal V, Venkatakrishnan AJ, Niesen MJM, et al. FDAauthorized mRNA COVID-19 vaccines are effective per real-world evidence synthesized across a multistate health system. Med (N Y). 2021;2(8):979-92 e8.

44. Puranik A, Lenehan PJ, Silvert E, Niesen MJM, Corchado-Garcia J, Horo JC, et al. Comparison of two highly-effective mRNA vaccines for COVID-19 during periods of Alpha and Delta variant prevalence. medRxiv. 2021:2021.08.06.21261707. doi: 10.1101/2021.08.06.21261707.

45. Angel Y, Spitzer A, Henig O, Saiag E, Sprecher E, Padova H, et al. Association Between Vaccination With BNT162b2 and Incidence of Symptomatic and Asymptomatic SARS-CoV-2 Infections Among Health Care Workers. JAMA. 2021;325(24):2457-65. doi: 10.1001/jama.2021.7152.

46. Chin ET, Leidner D, Zhang Y, Long E, Prince L, Schrag SJ, et al. Effectiveness of COVID-19 Vaccines among Incarcerated People in California State Prisons: A Retrospective Cohort Study. medRxiv. 2021:2021.08.16.21262149.

47. Stowe J, Andrews N, Gower C, Gallagher E, Utsi L, Simmons R, et al. Effectiveness of COVID-19 vaccines against hospital admission with the Delta (B.1.617.2) variant. Public Health England Publishing (June 14, 2021). 2021;Available at: https://khub.net/web/phe-national/public-library/-

/document library/v2WsRK3ZIEig/view/430986542

48. Office of the Premier of Ontario. Press Release: Ontario Moving to Step Three of Roadmap to Reopen on July 16. July 09, 2021. [Accessed August 30, 2021]. Available at:

https://news.ontario.ca/en/release/1000501/ontario-moving-to-step-three-of-roadmap-to-reopen-onjuly-16.

49. Province of Ontario. Roadmap to Reopen [Accessed August 30, 2021]. Available at: https://www.ontario.ca/page/reopening-ontario.

50. Province of Ontario. Ontario Makes COVID-19 Vaccination Policies Mandatory for High-Risk Settings. Press Release (August 17, 2021). Available at:

https://news.ontario.ca/en/release/1000750/ontario-makes-covid-19-vaccination-policies-mandatoryfor-high-risk-settings.

51. Pouwels KB, Pritchard E, Matthews PC, Stoesser N, Eyre DW, Vihta KD, et al. Impact of Delta on viral burden and vaccine effectiveness against new SARS-CoV-2 infections in the UK. Nuffield Department of Medicine, University of Oxford. 2021.

52. Paediatric Intensive Care Audit Network report on COVID-19 confirmed cases in PICU (published 8th July 2021): Universities of Leeds and Leicester.

53. Finelli L, Gupta V, Petigara T, Yu K, Bauer KA, Puzniak LA. Mortality Among US Patients Hospitalized With SARS-CoV-2 Infection in 2020. JAMA Netw Open. 2021;4(4):e216556.

54. Bhalala US, Gist KM, Tripathi S, Boman K, Kumar VK, Retford L, et al. Characterization and Outcomes of Hospitalized Children With Coronavirus Disease 2019: A Report From a Multicenter, Viral 
medRxiv preprint doi: https://doi.org/10.1101/2021.09.02.21263000; this version posted September 5, 2021. The copyright holder for this preprint (which was not certified by peer review) is the author/funder, who has granted medRxiv a license to display the preprint in perpetuity.

It is made available under a CC-BY-ND 4.0 International license .

Infection and Respiratory Illness Universal Study (Coronavirus Disease 2019) Registry. Crit Care Med. 2021.

55. Griffin JB, Haddix M, Danza P, Fisher R, Koo TH, Traub E, et al. SARS-CoV-2 Infections and Hospitalizations Among Persons Aged $\geq 16$ Years, by Vaccination Status - Los Angeles County, California, May 1-July 25, 2021. MMWR Morb Mortal Wkly Rep. 70(34):1170-6.

56. Our world in data. Canada: Coronavirus Pandemic Country Profile [Accessed August 30, 2021] Available at: https://ourworldindata.org/coronavirus/country/canada

57. Plantes PJ, Fragala MS, Clarke C, Goldberg ZN, Radcliff J, Goldberg SE. Model for Mitigation of Workplace Transmission of COVID-19 Through Population-Based Testing and Surveillance. Popul Health Manag. 2021;24(S1):S16-S25.

58. Mohanty S, Lakkireddy D, Trivedi C, MacDonald B, Quintero Mayedo A, Della Rocca DG, et al. Creating a safe workplace by universal testing of SARS-CoV-2 infection in asymptomatic patients and healthcare workers in the electrophysiology units: a multi-center experience. J Interv Card Electrophysiol. 2020. doi: 10.1007/s10840-020-00886-9.

59. Sandmann FG, White PJ, Ramsay M, Jit M. Optimizing Benefits of Testing Key Workers for Infection with SARS-CoV-2: A Mathematical Modeling Analysis. Clin Infect Dis. 2020;71(12):3196-203.

60. Paltiel AD, Zheng A, Sax PE. Clinical and Economic Effects of Widespread Rapid Testing to Decrease SARS-CoV-2 Transmission. Ann Intern Med. 2021;174(6):803-10.

61. Paltiel AD, Schwartz JL. Assessing COVID-19 Prevention Strategies to Permit the Safe Opening of Residential Colleges in Fall 2021. Annals of Internal Medicine. 2021. doi: 10.7326/M21-2965.

62. Centers for Disease Control and Prevention (CDC). School Testing for COVID-19 [Accessed August 30, 2021] Available at: https://www.cdc.gov/coronavirus/2019-ncov/community/schoolschildcare/school-testing.html. August 25, 2021.

63. Zhang Y, Johnson K, Lich KH, Ivy J, Keskinocak P, Mayorga M, et al. COVID-19 Projections for K12 Schools in Fall 2021: Significant Transmission without Interventions. medRxiv.

2021:2021.08.10.21261726. doi: 10.1101/2021.08.10.21261726.

64. Dick DW, Childs L, Feng Z, Li J, Röst G, Buckeridge DL, et al. Fall 2021 Resurgence and COVID-19 Seroprevalence in Canada Modelling waning and boosting COVID-19 immunity in Canada A Canadian Immunization Research Network Study. medRxiv. 2021:2021.08.17.21262188. doi:

10.1101/2021.08.17.21262188.

65. Cytrynbaum E, Otto S, Karlen D, Colijn C, von Bergmann J, James R, et al. COVID Model Projections - August 18, 2021 [Accessed August 30, 2021] Available at: https://bccovid19group.ca/post/2021-08-18-report/.

66. Public Health Agency of Canada. Update on COVID-19 in Canada: Epidemiology and Modelling. Mathematical modelling and COVID-19. July 30th, 2021;Available at: https://www.canada.ca/en/publichealth/services/diseases/coronavirus-disease-covid-19/epidemiological-economic-researchdata/mathematical-modelling.html.

67. McCoy DC, Cuartas J, Behrman J, Cappa C, Heymann J, López Bóo F, et al. Global estimates of the implications of COVID-19-related preprimary school closures for children's instructional access, development, learning, and economic wellbeing. Child Development. 2021. doi:

https://doi.org/10.1111/cdev.13658.

68. Science M, Thampi N, Bitnun A, Allen U, Birken C, Blackman N, et al. School Operation for the 2021-2022 Academic Year in the Context of the COVID-19 Pandemic. COVID-19 Science Advisory Table for Ontario. July 19, 2021.

69. Science Brief: Transmission of SARS-CoV-2 in K-12 Schools and Early Care and Education Programs - Updated (Last Updated July 9, 2021). [Accessed August 20, 2021] Available at: https://www.cdc.gov/coronavirus/2019-ncov/science/science-briefs/transmission k 12 schools.html. 
medRxiv preprint doi: https://doi.org/10.1101/2021.09.02.21263000; this version posted September 5, 2021. The copyright holder for this preprint

(which was not certified by peer review) is the author/funder, who has granted medRxiv a license to display the preprint in perpetuity.

It is made available under a CC-BY-ND 4.0 International license.

70. Lam-Hine T, McCurdy SA, Santora L, Duncan L, Corbett-Detig R, Kapusinszky B, et al. Outbreak Associated with SARS-CoV-2 B.1.617.2 (Delta) Variant in an Elementary School - Marin County, California, May-June 2021. MMWR Morb Mortal Wkly Rep. 2021;70(ePub: 27 August 2021. DOI: http://dx.doi.org/10.15585/mmwr.mm7035e2 ).

71. Centers for Disease Control and Prevention (CDC). Science Brief: Transmission of SARS-CoV-2 in K-12 Schools and Early Care and Education Programs - Updated [Accessed August 30, 2021] Available at: https://www.cdc.gov/coronavirus/2019-ncov/science/sciencebriefs/transmission k 12 schools.html. July 9, 2021. 